\title{
Efficient statute law
}

Citation for published version (APA):

Backhaus, J. G. (1997). Efficient statute law. METEOR, Maastricht University School of Business and Economics. METEOR Research Memorandum No. 038 https://doi.org/10.26481/umamet.1997038

Document status and date:

Published: 01/01/1997

DOI:

10.26481/umamet.1997038

Document Version:

Publisher's PDF, also known as Version of record

\section{Please check the document version of this publication:}

- A submitted manuscript is the version of the article upon submission and before peer-review. There can be important differences between the submitted version and the official published version of record.

People interested in the research are advised to contact the author for the final version of the publication, or visit the DOI to the publisher's website.

- The final author version and the galley proof are versions of the publication after peer review.

- The final published version features the final layout of the paper including the volume, issue and page numbers.

Link to publication

\footnotetext{
General rights rights.

- You may freely distribute the URL identifying the publication in the public portal. please follow below link for the End User Agreement:

www.umlib.nl/taverne-license

Take down policy

If you believe that this document breaches copyright please contact us at:

repository@maastrichtuniversity.nl

providing details and we will investigate your claim.
}

Copyright and moral rights for the publications made accessible in the public portal are retained by the authors and/or other copyright owners and it is a condition of accessing publications that users recognise and abide by the legal requirements associated with these

- Users may download and print one copy of any publication from the public portal for the purpose of private study or research.

- You may not further distribute the material or use it for any profit-making activity or commercial gain

If the publication is distributed under the terms of Article $25 \mathrm{fa}$ of the Dutch Copyright Act, indicated by the "Taverne" license above, 
Prepared for the New Palgrave Dictionary of Economics and the Law

\title{
Efficient Statute Law
}

\author{
Prof. Dr. Jürgen G. Backhaus \\ Maastricht University, AE \\ P.O. Box 616 \\ 6200 MD Maastricht \\ The Netherlands \\ tel: $+31-43-3883652 / 3636$ \\ fax: +31-43-3258440 \\ emai: f.schijlen@algec.unimaas.nl
}




\begin{abstract}
This article discusses the notion of efficient statute law. The hypothesis that the common law develops towards efficiency is the organizing principle of the new law and economics as it originated at the University of Chicago School of Law. However, the hypothesis can be regarded as too limited. In this article it is shown that statute law under specific circumstances can also be described as developing towards efficient solutions. This is shown in terms of a set of three models.
\end{abstract}

Key words: co-determination, background law, deal law, rent seeking

J.E.L. code: K00 


\section{Efficient Statute Law}

Due to its development from different sources such as common law and equity as brought across the ocean from England, the Code Civil in Louisiana, widely divergent state law, and federal statute law, regulations and jurisdiction, American civil law has traditionally been hard to comprehend and therefore also hard to teach. On the basis of the teachings at the University of Chicago School, notably by Aaron Director, Richard Posner built a legal doctrine and text book presentation of American law (Posner 1981), but notably American civil law, on the hypothesis that it can be described and taught as if it had been designed with economic efficiency in mind. This hypothesis seems to fly in the face of both legal history and the received body of public choice theory, including the economic theory of rent seeking. It is therefore necessary to show under what conditions we can expect the law to develop so as to facilitate market exchange, by reducing transactions costs and thereby allowing for a deep division of labour in the economy. This essay offers a simple model based discussion of why not only the common law but also statute law can be expected to develop towards efficiency, and spells out the conditions of this development. In conclusion, statute law moves towards efficiency not only through legislation but also through jurisdiction.

\section{The Debate on the Efficiency of the Common Law}

A steady flow of papers over recent decades in the economic analysis of law suggests that the common law evolves toward efficiency (Cooter \& Kornhauser 1980, Goodman 1978.

Hirshleifer 1982, Landes \& Posner 1979, Posner 1977 (2), Priest 1977, but with reservations, 
Rubin 1977, 1982, Terrebonne 1981); the implication being that statute law does not. There are others who disagree, e.g. Richard Posner is now "distinctly skeptical about the claim" (personal communication). The notion has nevertheless become so deeply rooted in the folklore of the law and economics subdiscipline that it has rendered meaningful discussions about efficient legislation by code or statute very difficult. Despite the different formulations, the suggestion turns on the proposition that inefficient law creates large transactions costs: hence, parties gain from having inefficient legal arrangements removed. It follows that inefficient legal rules will be litigated again and again, until they approach efficiency. Michelman (1980) showed that this tendency should hold for judicial behaviour under either type of law, common or enacted. We should therefore observe a tendency toward efficiency in judicial rule making, independent of the particular legal culture in which a judge opines. Whereas Michelman's amendment to the Posnerian argument considerably weakens the case for the superiority and singular efficiency of the common law, it refocuses attention on the body of law to which judicial decision making gives rise. That judicial decision making tends toward "efficient" (defined as wealth maximizing) legal rules (Posner 1981, Hofstra Law Review Symposium 1, 111980 and from a critical viewpoint, Samuels 1981) is quite consistent with another contention, dating back to Bentham (1789, Works 1838-1843, 1968), that the common law, as a system of rules, lacks coherence and rationality and hence is less efficient than a code (one might add "can conceivably be"). The successive judicial decisions groping towards efficiency may reach a local optimum, an optimum that can be inferior, as Pareto emphasized, to an inefficient solution reached otherwise.

Further doubt is cast on the notion that the common law converges towards efficiency, since the supposition that inefficient rules will be relitigated rests on the assumption that the judiciary is a monopolistic provider of legal decisions. Inefficient legal arrangements need not be re- 
litigated. Parties will engage in litigation only if each of them expects the benefits from litigation to exceed the costs. When inefficient verdicts are expected, parties will be reluctant to litigate and prefer rather to settle out of court. The tendency toward efficiency is not a dependable one. As Priest and Klein (1984) have shown, litigation depends largely on how close the parties estimate the dispute to remain to the court's established decision standard. "Close" cases are most likely to be re-litigated, as are those in which one party has a relatively larger stake than the other. It follows that both efficient and inefficient decision rules can be perpetuated (This begs a related question: Where will those parties turn that have been frustrated by inefficient court rulings? Answers to this question of substitute re-litigation will, of course, hinge on the availability of alternative sources of adjudication). Disregarding for the moment private avenues of adjudication, it appears that whether the law is efficient will depend more on the performance of legislatures than the prevailing literature suggests.

In the following section I propose three variations of a simple model to show under what conditions we can expect the legislature to enact efficient law.

\section{Three simple models}

In keeping with Michelman's (1980) distinction, we assume that there are two types of law in any society: law that every incremental enactment or judicial opinion builds on (Michelman calls it "background law), and law that was a "deal" to redistribute income away from one group and toward another. In this transfer, the legislator is seen as a broker who acts for a fee (McCormick \& Tollison 1981). "Deal law" may then be efficient in maximizing the wealth of the society in the long run, but it need not be. Conventionally, "background law" should tend toward efficiency, although my preceding remarks leave this supposition in doubt. 
"Background law" may be either common law or codified case law, consisting of pure codifications or a combination of these elements. Hence, we can assume, in each jurisdiction, a certain amount of competition between the legislature and the judiciary in providing "background law". While Michelman's distinction between "background law" and "deal law" is a straightforward one, identifying a particular piece of legislation as being either "background law" or "deal law" may be less so. It is perfectly possible that an act of parliament contains both. As Posner has pointed out, the distinction may require some deeper analysis in each individual case. He notes that "courts cannot readily identify purely redistributive legislation, in part because such redistributive legislation may be defensible on efficiency grounds by reference to problems of social peace, free rider problems and so forth" (See Richard A. Posner, 1987, at note 12).

Fortunately for the purpose of this essay, this distinction need not be operationalized (Aretz, 1993). For a study of a particular legislative process, the distinction would have to be established by developing a model that is able to capture the impact of the legislation on the performance of the affected natural or legal persons.

\section{A. Political Entrepreneurs}

Assume a legislature made up of representatives who broker their legislative services for a fee. They are individual wealth maximizers, an assumption which is standard in the American context although one may wonder whether it contains a reasonable description of political processes in Europe, where political parties tend to play a much greater role than in the United States. Still, important interest groups are expediently and reliably served by their parties or caucuses, and particular politicians specialize in particular interest groups. 
The demand for legislative income transfers is fairly straightforward. It requires a group so small that the benefit bestowed upon it is clearly perceptible for each member is sufficiently well organized as to prevent dissipation of the benefit and able to provide the necessary brokerage fee in terms of either votes or pecuniary (and lawful) benefits.

The suppliers of wealth transfers must, in turn, be difficult to organize and inelastic in their response to legislation. A threat of facing a one dollar loss as a consequence of legislation will not result in a one dollar increase in expenditure to fight it; the expected individual costs of mounting a political defence exceed the expected individual gains from not being coerced into a wealth transfer. The opportunity costs of resisting the wealth transfer must exceed the per capita amounts transferred.

The more durable the enactment and the larger the transfer it provides, the more the receiving interest group is willing to pay. Yet, for the providing group, the more durable the enactment and the larger the transfer, the higher will be the benefit from resisting the transfer, whereas opportunity costs remain unaffected. Hence, wealth transfers are subject to a scale restriction that is determined by the (transactions) costs of resisting them. We should therefore observe multiple small transfers involving different groups of suppliers.

The main cost element facing groups that are either seeking or resisting wealth transfers are start-up costs, hence once they are borne, they no longer affect marginal costs. Established interest groups, then, enjoy an advantage in both seeking and resisting wealth transfers. This advantage amounts to a strong incentive for an established clientele of transfer recipients. A transfer may be large and durable, yet only affect each supplier to a small extent. Still, the larger the group of suppliers and the larger or more durable the transfer (or both), the higher the benefits will be from resisting. Votes and wealth can be assumed to be convertible. Since 
brokers compete for wealth or votes, political entrepreneurs may seek out groups of suppliers and, in return for their votes, oppose transfer programmes on their behalf. The larger the group of suppliers involved, or the larger or more durable the transfer sought, the higher the probability that a competing broker will organize resistance to a proposed wealth transfer. It follows that "deal law" should be of relatively shorter durability than "background law". Likewise, "deal law" should strongly benefit established groups and only mildly harm small, scattered groups; that is, "deal law" should not impose considerable welfare losses on the general public. There are clearly tendencies in society that contain the social loss from rent seeking (Tullock 1980).

Assuming convertibility between wealth and votes, legislative brokers can either seek to serve established interest groups or appeal to large groups of general interest voters. They will probably do both; they have an incentive to produce legislation that benefits many while harming few. Generous transfers are largely precluded since a transfer that is perceptibly to benefit many must impose a heavy burden on a few. Such a transfer will not be supplied because the benefits from resisting it will generally exceed the opportunity costs of forgoing the resistance. It follows that legislative brokers have an incentive to produce legislation that is capable of producing wealth for the general public; the more durable this wealth-producing legislation, the larger the benefit from it and, presumably, the larger the expected return in votes. Legislators face incentives to produce durable wealth-enhancing legislation side by side with incentives to broker transfers of relatively limited duration. This holds true under the assumption that legislators have sufficient information. While obviously legislators are not omniscient, they can rely on their clients to possess and process the relevant information. Wealth reducing legislation will be brought to the attention of the legislators by those whose wealth is being affected as well as by the press. 
We conclude that brokers in the legislature face incentives to produce both efficient "background law" as well as (mildly) inefficient "deal law". "Mildly" inefficient is a deliberately loose term, since the argument is cast in terms of tendencies, not precisely quantifiable magnitudes. I mean to suggest that the (negative) welfare costs of deal law in this scenario will be relatively minor as compared to the (positive) welfare effects of background law.

\section{B. The Open Jurisdiction}

The second model differs from the first in two respects. It assumes that the jurisdiction is open in the sense that citizens and corporations can either resist or escape unwanted legislation. They may escape into other jurisdictions or into an extralegal domain within the jurisdiction, such as an underground or shadow economy. The first alternative is relatively straightforward, the equivalent to the small open economy in international trade theory. The smaller the jurisdiction and the more flexible the agents it comprises, the more elastic we can expect the evasive response to be. Even if the jurisdiction is "big" and closed, however, the room for avoidance may be substantial. Regulations can be avoided by taking up other lines of business. Conflicts can routinely be settled out of court or conflict prone transactions can be avoided altogether. Alternative forms of dispute resolution can be resorted to or initiated. Finally, producers can withdraw from market transactions and shift exchanges of goods and services into an organization designed to reduce transactions costs (Williamson 1981).

None of these developments is included in what has been labelled the shadow economy, which itself is reputed to be a sizable extralegal sector in advanced Western economies (Simon \& Witte 1982, Tanzi 1982). The shadow economy, then, can be assumed to provide scope for escape in addition to the avoidance strategies already listed above (Frey \& Ramser 1986, Frey 
\& Weck 1983).

This modification of our model has two implications: the larger the potential for evasive action, the smaller the citizens' incentive will be to resist "deal" law that aims at extracting transfers, and the smaller the extracted transfer, particularly in the long run. While this leaves the demand for transfers unaffected, increasing the scope for avoidance dries up the supply and raises the legislators' cost of providing transfers, or "deal laws".

Secondly, the larger the scope for escape, the stronger the competitive pressure will be on legislators to produce efficient legal arrangements. And the stronger those competitive pressures are, the more likely it is that the economy will experience an expansion of its production possibility frontier.

The efficiency effect of "deal law" when supply dries up is essentially secondary, that is, that efficiency loss occurs in terms of productive activities foregone in an economy. These are the opportunity costs of "deal law". Obviously, they depend on the extent to which opportunities for wealth production are foreclosed by "deal law". This effect implies that the general welfare loss of "deal law" increases with the scope for evasive action.

Where resistance to "deal law" weakens and transfers decline, a large number of "deal laws" will be enacted. This observation reinforces the aforementioned tendency for "deal laws" to be numerous but of relatively limited direct impact on attained wealth. By the same reasoning, however, "deal laws" contract the production possibility frontier of the economy as a whole and hence affect citizens' attainable wealth positions.

We can conclude that in an "open" jurisdiction, legislators face even stronger incentives to produce efficient "background law", whereas incentives to produce "deal law" become weaker relative to the first model. 


\section{Introducing Leviathan}

The third model expands on the second in featuring an open jurisdiction, a Leviathan legislature (Buchanan \& Brennan 1980) that seeks to maximize revenues from taxation, and a judiciary that adjudicates litigation by professional standards of jurisprudence and remains unaffected by the revenue maximization behaviour of the legislature. Hence, an independent judiciary is assumed. Model $\mathrm{C}$ is designed to capture the long-run implications of legislators' activities on the efficiency of the whole body of law.

In Leviathan models legislators are again assumed to maximize the sum of political profits from taxation, on the one hand, and regulation (i.e. "deal law") on the other. Taxation and regulation are not only interchangeable as political means. While policies based on either invariably burden the citizenry, the size and fertility of the tax base is itself affected by the extent of regulation (Posner, 1986) a trade-off long noted in economics. (See Backhaus \& Wagner 1987) Similarly the regulatory domain shrinks as the burden of taxation increases, and vice versa, reducing the burden of taxation opens up the regulatory domain. From this simple argument it follows that the production of "deal law" impairs the fertility of the tax base. Hence, "deal laws" generate negative externalities for the legislature as a whole by reducing the tax pie.

In the Leviathan literature (Buchanan \& Brennan 1980, Buchanan \& Lee 1982) it is customary to assume that Leviathan acts myopically. The long-run tax rate is assumed to exceed that rate which would yield the maximum stream of tax revenues; likewise the long-run regulatory intensity exceeds that regulatory intensity which would maximize the production of "deal law" in the long run. Frey and Ramser (1983) have shown, however, that the short-run optimization of tax rates as well as regulatory intensities (considered simultaneously) can yield 
overregulation in tandem with undertaxation. It then appears that Leviathan's myopia is at odds with the beast's appetite. Shortrun optimization does not yield a maximum political profit.

By way of clarification suppose there is a unicameral legislature (according to McCormick \& Tollison 1981 a unicameral legislative is more conducive to interest group, i.e. "deal law", legislation than a bicameral legislature, especially if the two houses are of uneven size) and delegates may be re-elected. Then we can classify the delegates into cohorts according to the length of their tenure in the legislature. Whereas seniority can safely be assumed to carry additional power, there will always be a cohort that contains more members than a given one chosen at random. The larger cohort will be composed of younger delegates than the smaller one. This rule applies to all but the youngest cohort, which will be the largest. Hence, votes tend to be concentrated with younger delegates. The longer the tenure of a delegate, the shorter is his expected future tenure, and thus the shorter his time horizon can be in taking political decisions. Empirically we also observe that elected officials' reelection probabilities are a positive function of the length of their past tenure. The empirical base is McCormick's and Tollison's (1981). In a majority voting system based on districts, districts will compote for the most viable candidates in order to garner a majority, notably in a multi-party system. An underresearched case is the Imperial German democracy. The leading politician of the (Catholic or ultra mountain) Centre party, Count Ballestrem, had his estate in Upper Silesia and was elected there for the district of Oppeln to the Imperial Diet in 1872. He was a leading adversary of Bismarck in the confrontation with the Pope, was first Vice president of the Diet (1890-93) and representative of Meppen at the very Western border of the Empire (1891-94) for the Royal Prussian Diet. The point is that districts will compete for candidates, and the competition will land the most viable candidates in the safest candidacies. 
The relatively lower reelection chance of younger representatives affects the length of their time horizon only insofar as political gains and losses of "deal law" can be more heavily discounted in the immediate future where reelection is uncertain. Long run effects, however, will be important for younger elected officials who can expect to be held responsible for "deal" legislation they supported. Hence, elder delegates should be observed to be more prone to "deal law" than younger delegates. Conversely, the "newcomers" are more likely to take a long-run view, since they stand a greater chance not only of being confronted with the adverse consequences of sizing down the tax base or regulatory domain but of profiting individually from a large future tax base and unimpaired regulatory domains. Their opportunity cost of exposing deals is lower than that of longer serving legislators; it may even be nil. Since powerful interest groups will turn primarily to senior legislators who can deliver better deals, exposing those deals may be the best strategy in trying to depose long serving incumbents. Thus, gains from exposing "deal law" and introducing "background law" are likely to be highest for junior candidates, even if their expected tenure in office may remain relatively low due to lower (re-)election chances. In turn, delegates who take a longterm view outnumber their elder colleagues; more particularly, they have an incentive to produce "background law" that broadens the tax base and increases its fertility by expanding the production possibility frontier of the economy. All this suggests that "deal laws" will often be opposed by younger politicians who try to build political coalitions of transfer victims, thus seeking votes in the present while preserving their political power base for the future. This tendency should be observable in particular where politicians can claim revenue sources or regulatory domains, i.e., when political property rights are allowed to develop.

\section{Conclusion}


Will democratic legislatures largely engage in producing "deal law" at the expense of providing the economy with "background law"? Under the strict assumptions that legislatures consist of political brokers who act in a Leviathan environment, the conclusion is a resounding no. Brokers in the legislatures face incentives to produce efficient "background law" as well as (mildly) inefficient "deal law".

Although these incentives hold in a closed jurisdiction, in an open jurisdiction legislators face even stronger incentives to produce efficient "background law", whereas incentives to produce "deal law" become weaker relative to the first model. Finally, taking a long-run view, one notes that "deal laws" will often be opposed by younger politicians who try to build political coalitions of transfer victims, thus seeking votes in the present and preserving their political power base for the future. This tendency should be observable in particular where politicians can claim revenue sources or regulatory domains, i.e., when political property rights are allowed to develop. 


\section{Bibliography}

Aretz, Edward (1993), Efficient Law, PhD Dissertation, Maastricht

Backhaus, Jürgen G. \& Wagner, Richard E. (1987), "The Cameralists: A Public Choice

Perspective", Public Choice, 53, pp. 3-20

Bentham, Jeremy (1789), An Introduction to the Principles of Morals and Legislation, London:

T. Payne \& Son. Re-issued, ed. J.H. Burns, H.L.A. Hart and F. Rosen, Oxford: Clarendon Press, 1996.

1970. Of Laws in General. Ed. H.L.A. Hart, London: Oxford University Press.

1838-43. The Works of Jeremy Bentham, 11 vols. Ed. J. Bowring, Edinburgh: William Tait

Buchanan, James M. \& Brennan, Geoffrey (1980), The Power to Tax. Analytical Foundations of a Fiscal Constitution, Cambridge, Cambridge University Press.

Buchanan, James M. \& Lee, Dwight R. (1982), "Politics, Time, and the Laffer Curve", Journal of Political Economy, 90, pp. 816-819.

Cooter, Robert \& Kornhauser, Lewis (1980), "Can Litigation Improve the Law Without the Help of Judges?", Journal of Legal Studies, 9, pp. 139-163

McCormick, Robert E. \& Tollison, Robert D. (1981), Politicians, Legislation, and the 
Economy. An Inquiry into the Interest Group Theory of Government. Boston/The Hague:

Martinus Nijhoff

Frey, Bruno S. \& Ramser, Hans Jurgen (1986), "Where are the Limits of Regulation?" Journal of Institutional and Theoretical Economics 142, pp. 571-580 (Zeitschrift für die gesamte Staatswissenschaft).

Frey, Bruno S. \& Weck, Hannelore (1983), "What Produces a Hidden Economy? An International Cross Section Analysis", Southern Economic Journal, 49, pp. 822-832.

Goodman, John C. (1978), "An Economic Theory of the Evolution of the Common Law", Journal of Legal Studies, 7, pp. 393-406

Hirschleifer, Jack (1982), "Evolutionary Models in Economics and the Law: Cooperation versus Conflict Strategies", Research in Law and Economics, 4, pp. 1-60

Michelman, Frank I. (1980), "Constitutions, Statutes, and the Theory of Efficient Adjudication", Journal of Legal Studies, 9, pp. 431-461

Landes, William M. \& Posner, Richard A. (1979), “Adjudication as a Private Good”, Journal of Legal Studies, 8, pp. 235-284

Posner, Richard A. (1981), The Economics of Justice, Cambridge, Harvard University Press 
Posner, Richard A. (1977 (2)) (1986)(3rd, ed.), The Economic Analysis of Law, Boston, Little Brown.

Posner, Richard A. (1987), "The Constitution as an Economic Document", George

Washington Law Review, 56 (4), pp. 4-38

Priest, George L. (1977), "The Common Law Process and the Selection of Efficient Rules", Journal of Legal Studies, 6, p. 65

Priest, George \& Klein, Benjamin (1984), "The Selection of Disputes for Litigation". Journal of Legal Studies, 13, pp. 1-55

Rubin, Paul H. (1977), "Why is the Common Law Efficient?”, Journal of Legal Studies, 6, pp. $51-63$

Rubin, Paul H. (1982), "Common Law and Statute Law", Journal of Legal Studies, 11, p. 205225

Samuels, Warren (1981), "Maximization of Wealth as Justice", Texas Law Review, 60, pp. $147-172$

Simon, Carl P. \& Witte, Ann D. (1982), Beating the System: The Underground Economy, Boston, Auburn House. 
Tanzi, Vito (Ed.) (1982), The Underground Economy in the United States and Abroad, Lexington, Heath.

Terrebonne, R. Peter (1981, “A Strictly Evolutionary Model of Common Law”, Journal of Legal Studies, 10, pp. 397-407

Tullock, Gordon (1980), "Efficient Rent Seeking", in: Buchanan, Tollison \& Tullock (Eds.), Toward a Theory of the Rent Seeking Society, College Station, Texas A\&M University Press, pp. 3-15

Williamson, Oliver E. (1981), "The Modern Corporation: Origigins, Evolution, Attributes", Journal of Economic Literature, 19, pp. 